\title{
Frozen Storage of Mouse Embryos by Vitrification
}

\author{
Tomohiro Kono* and Yukio Tsunoda \\ National Institute of Animal Industry, Tsukuba Norindanchi, \\ P.O. Box 5, Ibaraki 305 \\ *NODAI Research Institute, Tokyo University of Agriculture, \\ Setagaya-ku, Tokyo 156
}

(Accepted for publication April 22, 1987)

\begin{abstract}
Summary. In vitro and in vivo survival of the mouse embryos from one-cell to blastocyst stage frozen by vitrification method (Rall and Fahy, 1985) was investigated in the present study. The embryos were plunged into $\mathrm{LN}_{2}$ directly after exposure to the vitrification solution (VSI). The results were obtained as follows.

1) The viavility of embryos after freezing and thawing was high in 8-cell embryos $(86 \%)$ and morulae $(77 \%)$, and the lowest in one-cell eggs $(0 \%)$ frozen by procedure $\mathrm{A}$.

2) The live young were obtained after transfer of frozen-thawed embryos at all stages to recipients.

3) Although the viavility of blastocysts diluted gradually by VSI solution was low $(29 \%-44 \%)$, it was enhanced remarkably $(75 \%)$ when they were diluted with $2.0 \mathrm{M}$ glycerol-0.5 $\mathrm{M}$ sucrose and then $0.5 \mathrm{M}$ sucrose-PBI solution at room temperature. KEY WORDS; VITRIFICATION, RAPID FREEZING, MOUSE EMBRYO, TRANSFRR TEST. Jpn J Anim Reprod 33, 77-81, 1987

\section{ガラス化超急速凍結法によるマウス初期胚の生存性および移植試験}

\author{
河野 友宏* ・ 角田 幸生 \\ 農林水産省畜産試験場 **東京農業大学総合研究所 \\ 305 筑波農林研究団地内局，私書箱 5 号 *156 世田谷区桜丘1-1-1
}

哺乳動物初期胚の凍結保存技術は, Whittingham (1972) 並びに Wilmut（1972）によって独自に成功例 が報告されて以来，その操作技術の簡略化のために多方 面から膨大な研究がなされ短期間に目覚しい進歩を遂げ た。最近, 凍害保護物質を胚内部に浸透させた後, 泼を液 体窒素中あるいはガス中に直接投入する超急速凍結法に 関する研究報告がなされている（Rall and Fahy, 1985; Massip et al., 1986; Miyamoto and Ishibashi, 1986; Scheffen et al., 1986; Széll and Shelton, 1986; Williams and Johnson, 1986)。Fahy et al. (1984)は, 常圧下にて容易にガラス化状態で凍結する DMSO, acetamide, propylen glycol および polyethylene glycol (PEG) から成る凍結液（vitrification solution 1, VS1
液）を開発した。Rall and Fahy（1985）はここの VS1 液の胚に対する毒性を低温下 $\left(0-4^{\circ} \mathrm{C}\right)$ で操作することに より弱め, ガラス化超急速凍結したマウス 8 細胞期胚に おいて融解後高い生存性を得ることに成功した。本実験 は，1細胞期から胚盤期までのマウス初期胚をガラス化 超急速凍結し, 融解後の生存性並びに移植試験による産 子への発生能について調べ, VS1液を用いた当該法の有 効性を明らかにしようとした。

\section{材料と方法}

供試胚 CD-1 系成熟䧳マウスを用い, 5 iu の PMSG と hCG を48時間間隔で腹腔内注射して過排卵誘起させ た後，同系統の雄と交配した。 hCG 投与後 18-20 時間 
目に 1 細胞期卵， 42-44 時間目に 2 細胞期胚， 64-66 時 間目に 8 細胞期胚， 76-78 時間目に桑実胚および 90-92 時間目に胚盤胞をそれぞれ M2 液 (Fulton and Whittingham，1978）を用い常法に従い採取した。なお，1細 胞期卵は卵管膨大部より採取後, hyaluronidase (300 IU/ $\mathrm{ml}$ ) を含む M2 液で処理し，卵丘細胞を除去した後供試 した。

VS1 液 ガラス化凍結液 (VS1 液) は, Rall and Fahy （1985）に従い調整した。0.4\% BASを含む PBI 液 （Whittingham, 1971a）を基本液として用い, $20.0 \mathrm{w} / \mathrm{v} \%$ DMSO, $15.5 \mathrm{w} / \mathrm{v} \%$ acetamide, $10.0 \mathrm{w} / \mathrm{v} \%$ propylene glycol および $6.0 \mathrm{w} / \mathrm{v} \%$ PEG 8000 を含む混合液を作 製して $100 \%$ VS1 液とした。

脱水・凍結法 PBI 液にて 2 回洗浄した供試胚は, 先 ず室温下の $25 \% \mathrm{VS} 1$ 液に移し10分間静置（A法）ある いは $12.5 \%$ 並びに $25 \%$ VS1 液にそれぞれ 5 分間（B 法)ずつ浸漬した。次いで, 水片にて冷却されている培 養用ディシュ（Falcon， $\phi 35 \mathrm{~mm}$ ) 中の $50 \%$ VS1 液に 移し，10分間（A法）あるいは15分間（B法）静置した 後, $1.2 \mathrm{ml}$ セラムチューブ $(\phi 12 \mathrm{~mm}$, ポリプロピレン 製，住友ベークライト社）内の $100 \% \mathrm{VS} 1$ 液 $20 \mu \mathrm{l}$ 液 中に 10-20 個ずつ移し, さらに, 水水中で10分間 (A法) あるいは15分間（B法）平衡させた後, 直接液体窒素中 に投入して融解まで保存した。また，胚盤胞の一部は $0.25 \mathrm{ml}$ のプラスチックストローを用いて同様に凍結保 存したが，両者間の成績には差異が認められなかったの で，結果はとりまとめて表した。

融解・除去法 凍結胚は 1-7 日間液体窒素中に保存し た後, 水水中で融解した。融解臕は直ちに冷 $50 \%$ VS1 液に移して10分間静置し，次いで冷 $25 \%$ VS1 液に 10 分間浸漬した。その後，直接（A法）あるいは $12.5 \%$ VS1 液に 5 分間浸漬 (B法) 後, 回収胚を室温下の PBI 液に移して 3 分間静置し，さらに新鮮 PBI 液にて 2 回 洗浄した。また, 胚盤胞では融解後直ちに室温下の 2.0 $\mathrm{M}$ glycerol-0.5M sucrose-PBI 液に, 次いで $0.5 \mathrm{M}$ sucrose-PBI 液にそれぞれ 3 分間浸漬した後, 新鮮 PBI 液に移す希釈法（C法）についても合わせて検討した。

生存胚の判定 融解胚は, M16液 (Whittingham, $1971 b)$ を用いて, $37^{\circ} \mathrm{C}, 5 \% \mathrm{CO}_{2}, 95 \%$ 空気の炭酸ガ ス培養器内で 1-5 日間培養し, 胚盤胞あるいは増大胚盤 胞に発生したものを生存胚と判定した。なお，1および 2 細胞期胚は $100 \mu \mathrm{l} / \mathrm{ml}$ EDTA を添加した M16 液に て培湌した。

移植 受卵雌には, 精管結柇雄マウス（CD-1 系）と
交配し偽妊娠雌マウス（CD-1 系）を用い，胚盤胞に発 生した生存胚を為妊娠 3 日目の子宮あるいは1日目の卵 管内に移植した。

冷却・融解速度の測定 水水中より直接液体窒素中に 投入したセラムチューブおよびプラスチックストロ一内 VS1 液の冷却並びに融解速度を, 自動温度記録計 (CHINO, EB22005）に微小電極を接続して測定した。

\section{結 果}

VS1 液によって超急速凍結されたマウス初期胚の融解 後の形態, 培養および移植成績を Table 1 に示す。

Rall and Fahy（1985）の方法に準じたA法で涷結・ 融解および凍害保護物質の除去を行った場合，1細胞期 卵では融解後の回収胚の 46\% (25/54) が正常な形態を 示していたが，体外培養の結果わずか $3.7 \%(2 / 54)$ が 4 細胞期胚に発生したに過ぎなかった。 2 細胞期胚の生 存性は, 細胞期畉と比較して明らかに高く, 回収胚の 46\%（62/135）が泼盤胞に発生した。これらの内54肧を 6 匹の受卵雌に移植した結果，4 匹が妊娠し12匹 (22\%) の産子を得た。 8 細胞期および桑実胚では最も良い成績 が得られ, 融解胚培養後の生存性はそれぞれ $86 \%$ (81/ 94）および $77 \%(54 / 70)$ であった。また，それらを移 植後の産子への発生率は，それぞれ 44\% (23/52) 並び に $31 \%$ (16/51) であった。これに対し肧盤胞では, 融 解時に正常な形態と認められたものは $36 \%$ (26/72), 1 日培養後の増大胚盤胞への発生率は $29 \%(21 / 72)$ に 過ぎなかった。これらを受卵雌に移植した結果，4\% (9/21) が産子に発生した。

一方， $25 \% \mathrm{VS} 1$ 液による処理前に， $12.5 \% \mathrm{VS1}$ 液 による処理を加え，さらに $50 \%$ と $100 \%$ VS1 液への 浸漬時間を 5 分間延長したB法の場合, 融解後正常な形 態を有していた卵の割合および培養後の生存率は，1細 胞期卵拈よび肧盤胞ともにA法に比べ高い傾向がみられ た。すなわち，1 細胞期卵では融解後 62\%（16/26）が 正常な形態を示し，回収卵の $19 \%(5 / 26)$ が体外培養 により胚盤胞に発育した。これらの胚盤胞を 2 匹の受卵 雌に移植したところ，1匹の産子を得た。肧盤胞では融 解後の正常胚率および増大泼盤胞への発生率は, それぞ れ 60\% (27/45) 並びに 44\%（20/45）に向上し，また 移植試験の結果 $70 \%(14 / 20)$ が産子に発生した。

さらに，B法で涷結された肧盤胞を用いて融解後の凄 害物質の希釈を,室温下に拈いて $2.0 \mathrm{M}$ glycerol-0.5 M sucrose-PBI 液および $0.5 \mathrm{M}$ sucrose-PBI 液を用いて 試みた結果, 85\% (44/52) が正常な形態を有しており, 
Table 1. In vitro and in vivo development of mouse embryos frozen by vitrification method

\begin{tabular}{|c|c|c|c|c|c|c|c|}
\hline $\begin{array}{l}\text { Stage of } \\
\text { embryos }\end{array}$ & $\begin{array}{l}\text { Treat- } \\
\text { ments }^{1)}\end{array}$ & $\begin{array}{l}\text { No. of } \\
\text { embryos } \\
\text { recovered }\end{array}$ & $\begin{array}{c}\text { No. of } \\
\text { morphologically } \\
\text { normal embryos } \\
(\%)\end{array}$ & $\begin{array}{c}\text { No. of } \\
\text { embryos developed } \\
\text { to blastocyst } \\
\text { after culture } \\
(\%)\end{array}$ & $\begin{array}{l}\text { No. of } \\
\text { embryos } \\
\text { trans- } \\
\text { ferred }\end{array}$ & $\begin{array}{l}\text { No. preg- } \\
\text { nant/ } \\
\text { recipents }\end{array}$ & $\begin{array}{c}\text { No. of } \\
\text { live } \\
\text { young } \\
(\%)\end{array}$ \\
\hline \multirow[t]{2}{*}{1 Cell } & A & 54 & $25(46)$ & $0(0)$ & 0 & $0 / 0$ & $0(0)$ \\
\hline & B & 26 & $16(62)$ & $5(19)$ & 5 & $2 / 2$ & $1(20)$ \\
\hline 2 Cell & A & 135 & $91(67)$ & $62(46)$ & 54 & $4 / 6$ & $12(22)$ \\
\hline 8 Cell & A & 94 & $85(90)$ & $81(86)$ & 52 & $5 / 6$ & $23(44)$ \\
\hline Morula & A & 70 & $59(84)$ & $54(77)$ & 51 & $3 / 5$ & $16(31)$ \\
\hline \multirow[t]{3}{*}{ Blastocyst } & A & 72 & $26(36) \leftarrow$ & $21(29) \longleftarrow *$ & 21 & $3 / 3$ & $9(43)$ \\
\hline & B & 45 & $27(60) \quad * *$ & $20(44) \leftarrow * *$ & 20 & $2 / 2$ & $14(70)$ \\
\hline & $\mathrm{C}$ & 52 & $44(85)$ & $39(75) \leftleftarrows$ & 39 & $4 / 4$ & $23(59)$ \\
\hline
\end{tabular}

1) A: Embryos were processed according to Rall and Fahy (1985).

B: Embryos were exposed to $12.5 \%$ and $25 \%$ VS1 for $5 \mathrm{~min}, 50 \%$ and $100 \%$ VSl for $15 \mathrm{~min}$, respectively.

C: Embryos frozen by procedure B were diluted with $2.0 \mathrm{M}$ glycerol-0.5 M sucrose-PBI and then $0.5 \mathrm{M}$ sucrose-PBI solution.

** Significantly different by $\mathrm{X}^{2}$-test at $\mathrm{p}<0.01$.

Table 2. Cooling and warming rates $\left({ }^{\circ} \mathrm{C} / \mathrm{min}\right)$ of VS1 solution in the polypropylen tube or plastic straw plunged into $\mathrm{LN}_{2}$ or ice water

\begin{tabular}{|c|c|c|}
\hline $\begin{array}{c}\text { Temperature } \\
\left({ }^{\circ} \mathrm{C}\right)\end{array}$ & $\begin{array}{c}\text { Polyproylen } \\
\text { tube }\end{array}$ & Plastic straw \\
\hline \multicolumn{3}{|l|}{ Cooling } \\
\hline $0 \sim-20$ & 350 & 630 \\
\hline$-20 \sim-40$ & 320 & 1500 \\
\hline$-40 \sim-60$ & 250 & 2000 \\
\hline$-60 \sim-80$ & 210 & 2000 \\
\hline$-80 \sim-100$ & 140 & 2000 \\
\hline$-100 \sim-120$ & 100 & 1800 \\
\hline \multicolumn{3}{|l|}{ Warming } \\
\hline$-120 \sim-100$ & 270 & 3700 \\
\hline$-100 \sim-80$ & 200 & 2100 \\
\hline$-80 \sim-60$ & 140 & 1400 \\
\hline$-60 \sim-40$ & 80 & 1100 \\
\hline$-40 \sim-20$ & 50 & 530 \\
\hline$-20 \sim \quad 0$ & 20 & 180 \\
\hline
\end{tabular}

$\mathrm{A}$ 区に比べ有意差（ $\mathrm{p}<0.01 ）$ を認めた。また，胚盤胞 への発生率 $(75 \%)$ はA区 $(29 \%)$ および B区 $(44 \%)$ に比べ有意 $(\mathrm{p}<0.01)$ に高く, 受卵雌に移植後 $59 \%$ (23/39) が産子に発生した。

セラムチューブおよびプラスチックストローを用いた 場合の VS1 液の冷却並びに融解速度は, Table 2 示す。 冷却および融解速度ともにセラムチューブで実施した時 には比較的遅いのに対し, プラスチックストローでは極 めて速い值であった。0 $120^{\circ} \mathrm{C}$ の範囲における平均冷却
および融解速度は, 前者では $270^{\circ} \mathrm{C} / \mathrm{min}$ 並びに $130^{\circ} \mathrm{C} /$ $\min$ であったのに対し, 後者では $1600^{\circ} \mathrm{C} / \mathrm{min}$ 並びに $1500^{\circ} \mathrm{C} / \mathrm{min}$ と著しく速く，前者の值と比較するとそれ ぞれ 7 倍および12倍の速度であった。

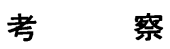

本実験は， Rall and Fahy（1985）が報告したガラス 化状態に固相化するVS1 を凍結液として用いたマウス 胚の超急速凍結法が， 8 細胞期胚のみならず 1 細胞期か ら胚盤胞期までのマウス初期発生胚の凍結保存に適用可 能なこと,さらに融解後の凍害保護物質の希釈・除去を, glycerol-sucrose 溶液を用いて室温下にて行らことによ り融解胚（胈盤胞）の生存性が著しく向上できることを 明らかにした。

哺乳動物卵子の耐凍能は, 発生段階により異なること が知られており, マウスでは 8 細胞期胚および桑実胚で 凍結・融解後の生存性が最も高く, 胚盤胞, 2 細胞期臕 の順に低下し，1 細胞期卵の生存性は最も低いことが知 られている (Whittingham, 1972; Leibo et al., 1974; 宮本·石橋, 1984; Miyamoto et al., 1986)。Rall and Fahy（1985）に従ってガラス化超急速凍結法でマウス初 期胚を凍結した本実験においても，1，2 細胞期胚およ び胚盤胞に比べて 8 細胞期肧並びに桑実胚で高い生存性 が得られた。Hsu et al. (1986) の当法を用いた実験結 果においても，8-16細胞期胚が胚盤胞に比べて高い生存 珄が得られている。VS1 液を用いたガラス化超急速凍 
結法による今回の成績は, DMSOを使用した緩慢凍結法 の結果（宮本・石橋，1984）々類似していた。初期肧の 耐凍能は凍害保護物質の細胞内への浸透が増加するに従 い高まること（Mazur，1970），並びに肧細胞内への凍 害保護物質の浸透は, 細胞容積に対する表面積の比が増 加するに従い，すなわち泼の分割が進むにつれ増加する こと（Mazur et al., 1976) が知られている。したがっ て, 初期胚の発生段階と耐凍能との関係には, 使用する 凍害保護物質によっても異なることが指摘されているが （浦野ら，1986），一般に胚の発生が進につれて耐凍能が 向上する傾向が認められる。また, 肧盤胞における耐凍 能の低下は胞肧腔内の水の脱水がされずらいことや, 融 解時における浸透圧障害が生じやすいことなどが考えら れる。泼の発生に伴う割球の膜の物質透過性, 浸透圧に 対する抵抗性あるいは細胞質の脱水性の変化も推察され ている（宮本・石橋, 1984)。

一方, 凍結・融解後培養によって発育した生存胚 242 個を，28匹の受卵雌に移植した結果，23匹が妊娠し全て の発生段階の凍結・融解胚から総数98匹の正常な産子が 得られた。これは妊娠が成立した受卵雌に移植された胀 198 個の $49 \%$ に当たり, 本実験における凍結・融解胚 は産子への発生能を十分有していることが確認された。

Fahy et al. (1984) の開発したVS1 液は, 常圧の条 件下で容易にガラス化状態で涷結して細胞内外の水晶形 成を防ぎ胚が受ける障害を回避できることから，マウス 初期胚の超急速凍結を可能とした。しかしながら，VS1 液は高濃度の涷害保護物質を含有しているため室温下で は強い、毒性が認められることから, 凍害保護物質の添加

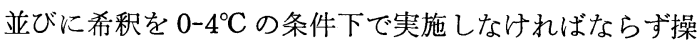
作が繁雑である。また，今回の実験成績では，8 細胞期 および桑実肧以外の発生段階のマウス肧では, 必ずしも 高い生存率が得られたとはいえない。その原因の 1 つと して, 融解後胚を $50 \%$ VS1 液から $25 \%$ VS1 液へ移し た際に胚細胞質の膨張が生じ，この傾向は $12.5 \%$ VS1 液あるいはP PBI 液に移すとさらに顕著な現象として観 察されたことから, 凍害保護物質の希釈時における浸透 圧変化による障害が考えられた。

融解胚からの DMSO の除去に対して sucrose が有効 であることが，マウス胚 (Kasai et al., 1980; Merry et al., 1983) および牛胚 (Niemann et al., 1982) で知 られている。そこで，VS1 液でガラス化凍結した胚盤 胞を氷水中で融解後, 直ちに室温下の $2.0 \mathrm{M}$ glycerol$0.5 \mathrm{M}$ sucrose-PBI 液に浸漬して凍害保護物質の希釈を 試みた (C法)。その結果, 融解胚の生存性は $75 \%$ と
$\mathrm{A}$ 法およびB法に比べて著しく向上し， sucroseを用い た希釈法が VS1 液による凍結肧に対しても優れた効果 を有することが判明した。また，室温下での凍害保護物 質の希釈が可能となり，その操作がかなり簡略化された と考学らる。

Scheffen et al. (1986) は, $10 \%$ glycerol-20\% 1.2propanendiol から成るガラス化凍結液を用いてマウス肧 を凍結し，融解後の希釈を $1 \mathrm{M}$ sucrose により実施して 良好な成績を得たと報告している。Massip et al. (1986) は, 同じ凍結方法を用いて牛胚をガラス化凍結し, 融解 後約 $40 \%$ の生存胚が得られたと報告している。また， sucrose-glycerol-PBI 液による超急速凍結法がマウス泼 (Willams and Jonson, 1986; Széll and Shelton, 1986) および牛肧（Bui-Xuan-Nguyen et al., 1984）において 試みられており, 融解後の比較的高い生存性を得ること に成功している。さらに, VS1 液を用いてガラス化凍結 した人の単核白血球は, 融解後 $92 \%$ の細胞が正常な機 能を有していることが明らかにされている（Takahashi et al., 1986)。

今後, ガラス化凍結法のさらに広範な対象への利用, 並びに信頼度が高くしかも簡略な凍結法の開発に向けて 研究が進展するものと考光られる。

\section{謝辞}

謝辞本論文を作成するにあたり有益な御助言並びに 御校閲を頂いた東京農業大学総合研究所教授中原達夫博 士, 当場繁殖部長花田 章博士並びに家玄改良事業団家 畜改良センター杉江 佶博士に感謝致します。

\section{References}

Bui-Xuan-Nguyen N, Heyman Y, Renard JP (1984) Direct freezing of cattle embryos after partial dehydration at room temperature. Theriogenology 22: 389-399.

Fahy GM, Macfarlane DR, Angell CA, Meryman HT (1984) Vitrification as an approach to cryopreservation. Cryobiology 21: 407-426.

Fulton BP, Whittingham DG (1978) Activation of mammalian oocytes by intracellular injection of calcium. Nature 273: 149-151.

Hsu TT, Yamakawa H, Yamanoi J, Ogawa S (1986) Survival and transfer test of mouse early embryos frozed by vitrification method. Jpn J Anim Reprod 32: 106-109.

Kasai M, Niwa K, Iritani A (1980) Survival of mouse embryos frozen and thawed rapidly. $J$ Reprod Fert 59: 51-56. 
Leibo SP, Mazur P, Jackowski SC (1974) Factors affecting survival of mouse embryos during freezing and thawing. Expl Cell Res 89: 79-88.

Mazur P (1970) Cryobiology: The freezing of biological systems. Science 168: 939-949.

Mazur P, Rigopoulos N, Jackowski SC, Leibo SP (1976) Preliminary estimates of the permeability of mouse ova and early embryos to glycerol. Biophys $J$ 16: 223a, Abstr.

Massip A, Van Der Zwalmen P, Scheffen B, Ectors F (1986) Pregnancies following transfer of cattle embryos preserved by vitrification. Cryo-Letters 7: 270-273.

Merry DA, Allen RL, Krag K, Wright RW,Jr (1983) Sucrose dilution of frozen mouse embryos: interaction of glycerol and sucrose concentrations. Theriogenology 20: 325-332.

Miyamoto H, Ishibashi T (1984) Effects of embryonic stages on survival of frozen-thawed mouse embryos. J Mamm Ova Res 1: 95-98 (in Japanese).

Miyamoto H, Ishibashi $\mathrm{T}$ (1986) Liquid nitrogen vapour freezing of mouse embryos. $J$ Reprod Fert 78: 471-478.

Miyamoto H, Miyamoto Y, Ishibashi T (1986) The importance of equilibration time to glycerol prior to freezing in the cryopreservation of mouse embryos. Jpn J Zootech Sci 57: 250-256.

Niemann H, Sacher B, Schilling E, Smith D (1982) Improvement of survival rates of bovine blastocysts with sucrose for glycerol dilution after a fast freezing and thawing method. Theriogenology 17: $159-166$
Rall WF, Fahy GM (1985) Ice-free cryopreservation of mouse embryos at $-196^{\circ} \mathrm{C}$ by vitrification. Nature 313: 573-575.

Sheffen B, Van Der Zwalmen P, Massip A (1986) A simple and efficient procedure for preservation of mouse embryos by vitrification. Cryo-Letters 7: 260-269.

Széll A, Shelton JN (1986) Sucrose dilution of glycerol from mouse embryos frozen rapidly in liquid nitrogen vapour. J Reprod Fert 76: 401-408.

Takahashi T, Hirsh A, Erbe EF, Bross JB, Steere RL, Williams RJ (1986) Vitrification of human mnocytes. Cryobiology 23: 103-115.

Urano K, Takahasi Y, Kanekawa H (1986) Effect of various cryoprotectants on the survival of frozenthawed mouse embryos. Jpn J Anim Reprod 32: 130-133 (in Japanese).

Whittingham DG (1971 a) Survival of mouse embryos after freezing and thawing. Nature 233: 125-126.

Whittingham DG (1971 b) Culture of mouse ova. J Reprod Fert, Supple 14: 7-21.

Whittingham DG (1972) Survival of mouse embryos to -196 and $-269^{\circ} \mathrm{C}$. Science 178: $411-414$.

Williams TJ, Johnson SE (1986) A method for onestep freezing of mouse embryos. Theriogenology 26: $125-133$.

Wilmut I (1972) The effect of cooling rate, warming rate, cryoprotective agent and stage of development on survival of mouse embryos during freezing and thawing. Life Sci 11: 1071-1079.

\section{要 約}

1 細胞期から胚盤胞までのマウス初期肧をVS1 液を用いたガラス化超急速凍結法により凍結し， 融解後の生存性並びに移植後の産子への発生能について検討した。

1. 融解後の生存性は，8 細胞期胚（86\%）並びに桑実胚（77\%）で高く，A法で涷結された 1 細 胞期卵 $(0 \%)$ で最も低かった。

2. 移植試験の結果, 1 細胞期から胚盤胞をでの全ての発生段階の融解肧から産子を得ることがで きた。

3. 肧盤胞において融解後の凍害保護物質の希釈を, $2.0 \mathrm{M}$ glycerol-0.5 M sucrose-PBI 液次いで $0.5 \mathrm{M}$ sucrose-PBI 液で行い, 生存性を著しく向上（75\%) させることができた。 